\title{
Effect of Platinum loading on Graphene Nano Sheets at Cathode
}

\author{
RIKSON SIBURIAN ${ }^{1 *}$, KERISTA SEBAYANG ${ }^{2}$, \\ MINTO SUPENO ${ }^{1}$ and HARLEM MARPAUNG ${ }^{1}$
}

\begin{abstract}
${ }^{1}$ Chemistry Department, Faculty of Mathematic and Natural Science,
University of Sumatera Utara, Medan 20500, Indonesia.

${ }^{2}$ Nanomedicine Center-University of Sumatera Utara, Stem cell- University of Sumatera Utara.

*Corresponding author E-mail: riksonsiburian2000@yahoo.com
\end{abstract}

http://dx.doi.org/10.13005/ojc/330114

(Received: December 01, 2016; Accepted: January 29, 2017)

\begin{abstract}
The effect of Pt loading on graphene nanosheets (GNS) at electrode catalyst fuel cell was carried out. The purpose of this research is to know the effect of Pt loading on GNS and support material for catalytic activity of Pt/GNS. The results show $20 \mathrm{wt} \% \mathrm{Pt} / \mathrm{GNS}$ is highest catalytic activity among the others and the catalytic activity of Pt on GNS is higher than that of Pt on carbon black (CB) commercial catalyst. A core level shift of Pt $4 \mathrm{f}$ in XPS indicates that Pt is chemically interacted with GNS. It has been ascribed to the difference in the interface interaction between Pt and graphene via different strength of the $\delta-d$ hybridization.
\end{abstract}

Keywords: Pt, graphene nanosheet, Pt subnano-clusters, ORR.

\section{INTRODUCTION}

Polymer electrolyte membrane fuel cells (PEMFC) are being developed as electrical power sources for vehicles and portable applications as an alternative to conventional internal combustion engines, secondary batteries, and other conventional power sources. Generally, the requirements for catalyst support materials can be summarized as: high specific surface area, low combustive reactivity, high electrochemical stability, high conductivity, and interaction between catalytic metals and the support materials should be considered in improving the catalytic activity and durability. ${ }^{1}$

Recently, the design of cheap and stable fuel cell catalysts for catalyst electrode (oxygen reduction reaction (ORR)) at cathode is main challenge. ${ }^{2}$ Catalysts exhibit great influence on both the cost and the durability of PEMFC. ${ }^{3}$ The platinum nanoparticles 
supported on carbon black (Pt/CB) are most used for ORR catalysts. It has outstanding catalytic and electrical properties and superior resistant characteristics to corrosion. ${ }^{4}$ Therefore, much of the art and science of catalysts development for the ORR rely on both the fundamental understanding of the reaction at the Pt electrolyte interface and the optimization of the catalytic properties of the $\mathrm{Pt}$ surface. ${ }^{5}$ However, Pt price is expensive and also it is limited natural resources. ${ }^{6}$ So, it is a prerequisite to decrease the usage of $\mathrm{Pt}$ and enhance the catalytic activity of $\mathrm{Pt}$ in order to achieve a competitive low cost of fuel cell.

The catalyst support materials exhibit great influence on the cost, performance, and durability of PEMFC. For instance, carbon-supported precious metal nanoparticles (e.g., Pt, $\mathrm{Au}, \mathrm{Pd}$, and $\mathrm{Rh}$ ) are widely used in heterogeneous catalysis and electrocatalysis. ${ }^{7}$ The support materials are necessary to obtain a high dispersion, narrow distribution of $\mathrm{Pt}$ and Pt-alloy nanoparticles and also can interplay with catalytic metals, which is the prerequisite to obtain the high catalytic performance of catalysts. ${ }^{1}$ Commonly, the catalyst support materials require high specific surface area, high conductivity, low combustive reactivity under both dry and humid air conditions at low temperatures $\left(150^{\circ} \mathrm{C}\right.$ or less), high electrochemical stability under fuel cell operating conditions, easy to recover Pt in the used catalyst, ${ }^{1,8}$ and the interaction between catalytic metals and the support materials. ${ }^{9}$ This is because the interaction between the support and metal catalyst can modify the electronic structure of catalytic metals which in turn changes the catalytic activity. ${ }^{10}$. However, the weak interaction between metal and carbon supports results in a severe sintering/agglomeration of catalytic metal nanoparticles and consequently decreases the active surface area, which leads to the degradation of performance under long-term operations. ${ }^{7}$ Many researchers have reported novel carbon support materials, such as carbon nanohorns, ${ }^{11}$ carbon nanocoils, ${ }^{12}$ carbon nanotubes $(\mathrm{CNT}),{ }^{13}$ graphite nanofibers (GNFs),${ }^{14}$ and carbon black $^{15}$ for PEMFC applications. Some papers also reported that nitrogen-doped carbon nanotubes (N-CNT) with metal catalysts or without metals on them show enhancement catalytic activity toward ORR. ${ }^{16}$ They showed promising results toward fuel cell electrode reactions: ORR and methanol oxidation reaction (MOR). But, in term of activity, cost and durability, current catalysts can still not satisfy the requirements of target PEMFC. ${ }^{17}$ Therefore, many efforts are still necessary to find the novel catalytic metals and support materials.

Graphene sheets, a two-dimensional carbon material with single (or a few) atomic layer has attracted great attention for both fundamental science and applied research. This is caused it has large surface area $\left(2630 \mathrm{~m}^{2} \mathrm{~g}^{-1}\right),{ }^{18}$ and high carrier mobility $\left(10^{4} \mathrm{~cm}^{2} \mathrm{~V}^{-1} \mathrm{~s}^{-1}\right.$ at room temperature)..$^{19}$ Recently, graphene as a supporting material for Pt catalyst are believed to improve catalytic activity for hydrogen oxidation reaction (HOR) and methanol oxidation reaction (MOR). However, the controversial results regarding the ORR activity for Pt/GNS compare to $\mathrm{Pt} / \mathrm{CB}$ commercial catalyst. Moreover, fuel cell tests with Pt/GNS catalysts as cathode materials showed a considerably lower performance than that of the cell with $\mathrm{Pt} / \mathrm{CB}$ as cathode catalyst. ${ }^{20}$

In this paper, we studied the effect of $\mathrm{Pt}$ loading on GNS for hydrogen fuel cell. We focus about the ORR catalytic activity of Pt/GNS, it is caused the ORR at the cathode of fuel cells plays a key role in controlling the performance of a fuel cell, and the efficiency of ORR electrocatalysts are essential for fuel cells practical applications. ${ }^{21}$

\section{EXPERIMENTAL}

\section{Preparation of graphene and, Pt/GNS catalysts}

Graphene was prepared by the oxidation of graphite powder using the modified Hummers method. ${ }^{22}$ Briefly, graphite powder $(0.2 \mathrm{~g})$ (C $(98 \%)$, particle size $45 \mathrm{im}$, Wako Pure Chemical Industries, Ltd.) and sodium nitrate $\left(\mathrm{NaNO}_{3}\right)(0.16 \mathrm{~g})$ were first stirred in concentrated sulphuric acid (95 wt $\left.\% \mathrm{H}_{2} \mathrm{SO}_{4}\right)(6.7 \mathrm{~mL})$ for $2 \mathrm{~h}$ while being cooled in an ice water bath. Then, potassium permanganate $\left(\mathrm{KMnO}_{4}\right)(0.9 \mathrm{~g})$ was gradually added to form a new mixture. After $4 \mathrm{~h}$ in an ice water bath, the mixture was allowed to stand for $48 \mathrm{~h}$ at room temperature with gentle stirring. Thereafter, $20 \mathrm{~mL}$ of $5 \mathrm{wt} \% \mathrm{H}_{2} \mathrm{SO}_{4}$ aqueous solution was added into the above mixture over $1 \mathrm{~h}$ with stirring. Then, $0.5 \mathrm{~mL}$ of $\mathrm{H}_{2} \mathrm{O}_{2}(30 \mathrm{wt}$ $\%$ aqueous solution) was also added to the above liquid and the mixture was stirred for $2 \mathrm{~h}$. After that, $20 \mathrm{~mL}$ of $3 \mathrm{wt} \% \mathrm{H}_{2} \mathrm{SO}_{4} / 0.5 \mathrm{wt} \% \mathrm{H}_{2} \mathrm{O}_{2}$ solutions was 
added into suspension and centrifuged (3000 rpm, $1 \mathrm{~h}$ ). Subsequently, the product was dispersed in water and ultrasonicated for $5 \mathrm{~h}$. This process affords material of oxidized graphene nanosheets (OGS). ${ }^{23}$ Finally, the OGS were reduced with hydrazine hydrate at room temperature for $48 \mathrm{~h}$. This product was filtered and washed with distilled water and dried in air at RT for $24 \mathrm{~h}$. The as-received powder is the so-called graphene nano sheets (GNS). The detail characterization of GNS can be seen in reference as we reported previously. ${ }^{24}$

To prepare $10-70 \mathrm{wt} \% \mathrm{Pt} / \mathrm{GNS}$ catalysts, the calculated amount of $\mathrm{Pt}$ precursor $\mathrm{H}_{2} \mathrm{PtCl}_{6} \cdot 6 \mathrm{H}_{2} \mathrm{O}$ (Alfa Aesar, A Johnson Matthey Company) were dissolved in $50 \mathrm{~mL}$ ethanol. Subsequently, each of ethanol solution of the precursor was mixed with ethanol solution of GNS. After stirring solution for $3 \mathrm{~h}$, each of the products was collected by filtration and dried in air at $60{ }^{\circ} \mathrm{C}$ for $12 \mathrm{~h}$. Each of them was then reduced by a hydrogen stream $25 \mathrm{~mL} / \mathrm{min}$ at $400{ }^{\circ} \mathrm{C}$ for $2 \mathrm{~h}$ in a furnace. Finally, the catalysts were collected and denoted as 10-70 wt \% Pt/GNS catalysts. The amount of Pt on GNS was measured by thermogravimetric/differential thermal analysis (TG/DTA) (see in reference 25). This data shows that the Pt atoms of the catalyst precursor are well deposited on GNS.

Then, the 10-70 wt \% Pt/GNS were characterized XPS and electrochemical measurement. XPS measurements were carried out using JEOL JPS 9010 TR (X-ray source Al Ká, $1486.6 \mathrm{eV}$; pass energy $50 \mathrm{eV}$, energy resolution $1.88 \mathrm{eV}$ which was calibrated using $\mathrm{Ag} 3 \mathrm{~d}_{5 / 2}$ by measuring a clean $\mathrm{Ag}$ sample, the uncertainty of binding energy $\pm 0.05 \mathrm{eV}$ ). TEM (JEOL JEM1400 electron microscope was operated at $80 \mathrm{kV}$, resolution lattice image $0.20 \mathrm{~nm}$, and resolution point image $0.38 \mathrm{~nm}$. TG/DTA measurements were carried out using TG/DTA6300, Seiko Instruments Inc. (Reference: Pt; Air 200 mL/min; T measurement: 50-1000 ${ }^{\circ} \mathrm{C}$; Rate: $10^{\circ} \mathrm{C} / \mathrm{min}$ ), respectively.

\section{Electrochemical measurement}

The ORR activities of GNS and 10-70 wt $\% \mathrm{Pt} / \mathrm{GNS}$ catalysts, respectively were assessed by using cyclic voltammetry (CV), and rotating ring disk electrode (RRDE) (PGSTAT PG12, AUTOLAB Potensiostat/Galvanostat) measurements in $0.1 \mathrm{M}$
$\mathrm{HClO}_{4}$. The catalyst ink was prepared by dispersing $1 \mathrm{mg}$ catalyst in the mixture of $500 \mathrm{iL} \mathrm{(1:50} \mathrm{in}$ methanol) $5 \mathrm{wt} \%$ Nafion solutions (Aldrich), then the mixture of catalyst ink was sonicated for 60 minutes. Then, $10 \mathrm{iL}$ of catalyst ink was transferred onto the polished glassy carbon disk (diameter $=5$ $\mathrm{mm}$, geometric area $=0.283 \mathrm{~cm}^{2}$ ) and dried to form a thin catalyst layer. The catalysts loading on the glassy carbon are 20 ig for GNS.

The Pt loadings of catalysts on the glassy carbon are 2.0, 3.0, 4.0, 5.0, 6.0, 7.0, 8.0, 9.0, 10.0, 11.0 , and 12.0 ig for $10,15,20,25,30,35,40,45$, $50,55,60,65$, and 70 wt \% Pt/GNS, respectively. The CV measurement was carried out by using a typical three-electrode systems consist of a working electrode (glassy carbon), a Pt wire as a counter electrode, and a reversible hydrogen electrode (RHE) as a reference electrode. All measurements were performed at room temperature $\left(<" 25{ }^{\circ} \mathrm{C}\right)$ using a fresh electrolyte solution $\left(0.1 \mathrm{M} \mathrm{HClO}_{4}\right.$, Sigma-Aldrich). First, the catalyst on the working electrode was purged by bubbling nitrogen $\left(\mathrm{N}_{2}\right)$ gas at $200 \mathrm{~mL} \mathrm{min"1} \mathrm{through} 0.1 \mathrm{M} \mathrm{HClO}_{4}$ for 20 minutes. Then, it was scanned at $0.05-1.0 \mathrm{~V}$ versus RHE for 50 cycles with scan rate $10 \mathrm{mV} \mathrm{s}^{-1}$ and rotation rate $500 \mathrm{rpm}$ in $\mathrm{N}_{2}$ to eliminate contaminant and de-oxygenates the environment. After that, the saturation gas was switched to oxygen $\left(\mathrm{O}_{2}\right)$ for RRDE measurement, and the electrolyte was saturated for the same condition as CV measurement. The RRDE polarization curves were obtained at $0.05-1.0 \mathrm{~V}$ versus $\mathrm{RHE}$ with scan rate $10 \mathrm{mV} \mathrm{s}{ }^{\prime 1}$ in $\mathrm{O}_{2}$ saturated $0.1 \mathrm{M} \mathrm{HClO}_{4}$. The commercial catalysts of 20 and 40 wt \% Pt/carbon black (CB) (Johnson Matthey) were used as comparison.

\section{RESULTS AND DISCUSSION}

\section{ORR of $10-70$ wt \% Pt/GNS, and Pt/CB commercial catalysts}

Figure $1 a$ and $b$ shows the ORR polarization curves and ORR catalytic activity for 10-70 wt \% $\mathrm{Pt} / \mathrm{GNS}$ and 20 and $40 \mathrm{wt} \% \mathrm{Pt} / \mathrm{CB}$ commercial catalysts, respectively. In the case of 10,15 and 20 wt $\% \mathrm{Pt} / \mathrm{GNS}$, catalysts, the ORR catalytic activity increases with increasing Pt amount on GNS (0.93 to $0.99 \mathrm{~V}$ versus $\mathrm{RHE}$ ). Then, the ORR catalytic activity gradually decreases with increasing $\mathrm{Pt}$ amount on GNS for 25-70 wt \% Pt/GNS. Their 
onset potentials are decreased from 0.99 to $0.85 \mathrm{~V}$ versus $\mathrm{RHE}$ for $25-70$ wt \% Pt/GNS. It indicates that the ORR activities tend to decrease with increasing Pt particle size (Figure 1b). The current density was measured at $0.9 \mathrm{~V}$ versus $\mathrm{RHE}$ for $10-70 \mathrm{wt}$ $\% \mathrm{Pt} / \mathrm{GNS}$ and 20 and 40 wt \% Pt/CB commercial catalysts are shown in Figure 2. In the case of
10-20 wt \% Pt/GNS catalysts, the current densities increase with increasing Pt amount (0.03 to $0.9 \mathrm{~V}$ versus $\mathrm{RHE}$ ). Then, their current densities decrease with increasing Pt amount for 25-70 wt \% Pt/GNS catalysts. It is also consistent with the ORR data. These data indicate that Pt particle size affects the ORR activity for Pt/GNS catalysts. Interestingly, 20 wt

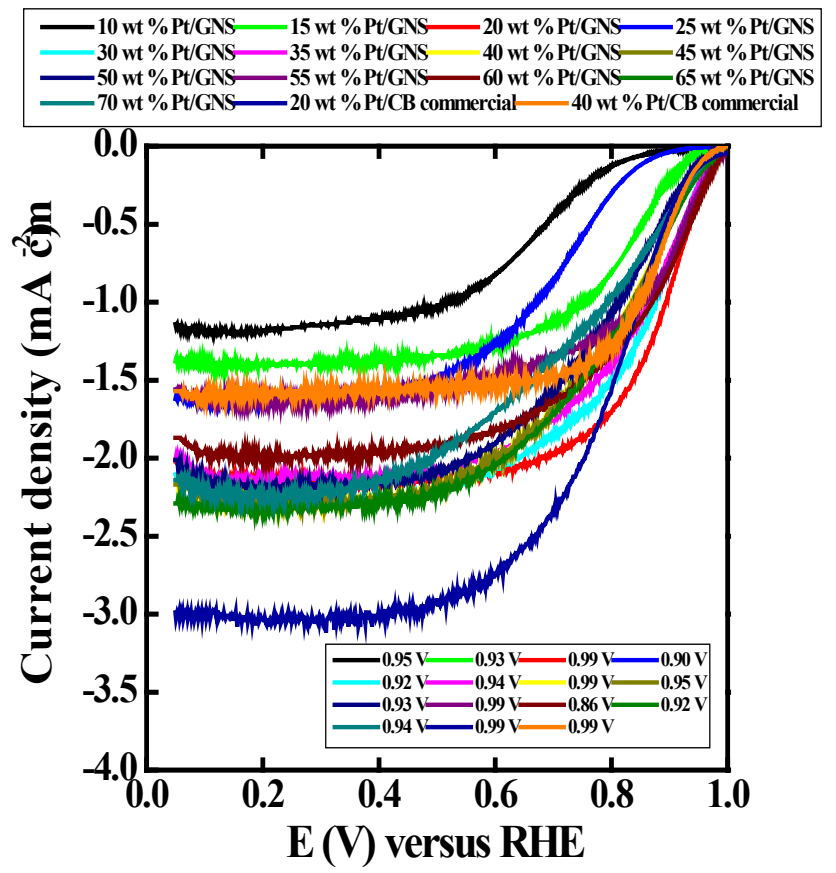

Fig. 1a: RRDE polarization curves of 10-70 wt \% Pt/GNS and Pt/CB commercial catalysts in $\mathrm{O}_{2}$-saturated $0.1 \mathrm{M} \mathrm{HClO}_{4}$ solution. Scan rate is $10 \mathrm{mVs}^{-1}$, respectively

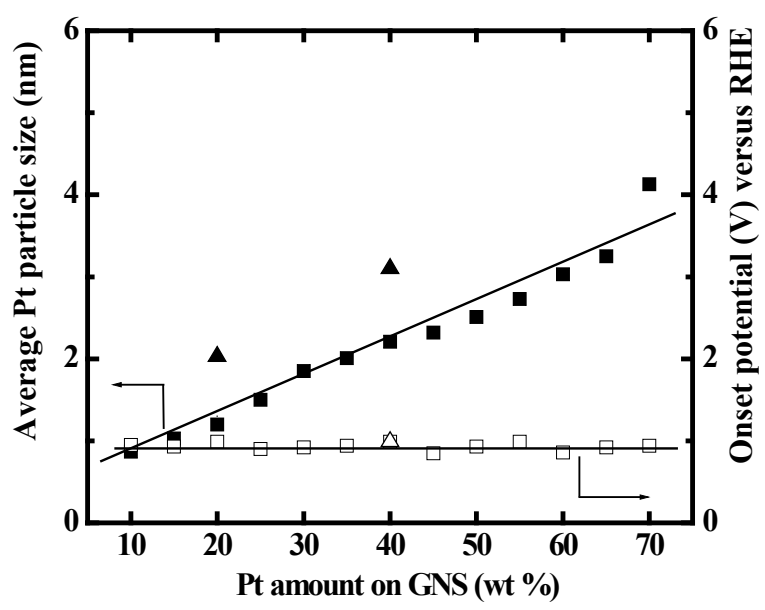

Fig. 1b: Average Pt particle size (nm) ( \% Pt/GNS, $2 \% \mathrm{Pt} / \mathrm{CB}$ ) and onset potential (V) ( $¡ \%$ Pt/GNS, Ä Pt/CB) versus Pt amount on GNS 
$\% \mathrm{Pt} / \mathrm{GNS}$ catalyst shows the higher ORR catalytic activity than $20 \mathrm{wt} \% \mathrm{Pt} / \mathrm{CB}$ commercial catalyst. The 20 wt \% Pt/GNS exhibits the highest ORR activity from its onset potential ( $0.99 \mathrm{~V}$ versus $\mathrm{RHE})$ and half wave potential $\left(E_{1 / 2} \mathrm{H}\right.$ " $0.88 \mathrm{~V}$ versus $\left.\mathrm{RHE}\right)$ among the other catalysts. This is also consistent with its current density 0.9 to $0.4 \mathrm{~mA} \mathrm{~cm}^{-2}$ measured at $0.9 \mathrm{~V}$ versus $\mathrm{RHE}$, for $20 \mathrm{wt} \% \mathrm{Pt} / \mathrm{GNS}$ and $\mathrm{Pt} / \mathrm{CB}$, respectively. This is a good new where the GNS is better than CB as a supporting material for cathode catalyst.

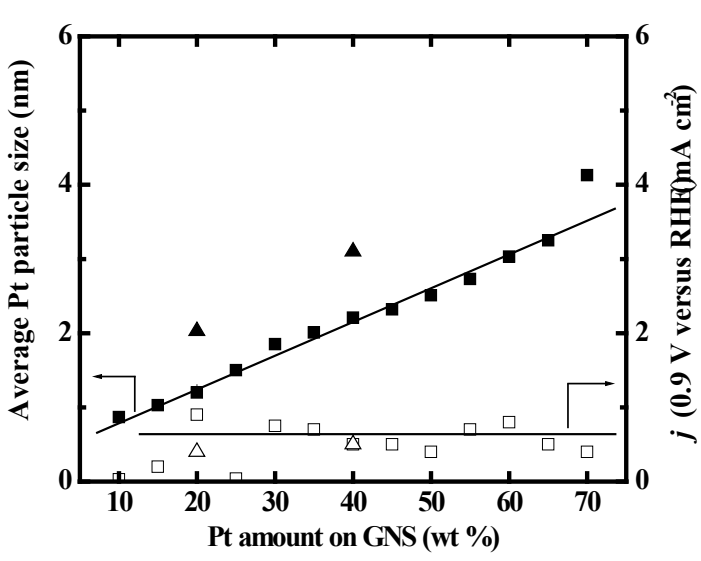

Fig. 2: Average Pt particle size ( $\mathrm{nm}$ ) (\% Pt/GNS, $2 \% \mathrm{Pt} / \mathrm{CB}$ ) and current density at $0.9 \mathrm{~V}$ versus RHE $\left.(\mathrm{mA} \mathrm{cm})^{-2}\right)(i \% \mathrm{Pt} / \mathrm{GNS}$, Ä Pt/CB) versus $\mathrm{Pt}$ amount on GNS

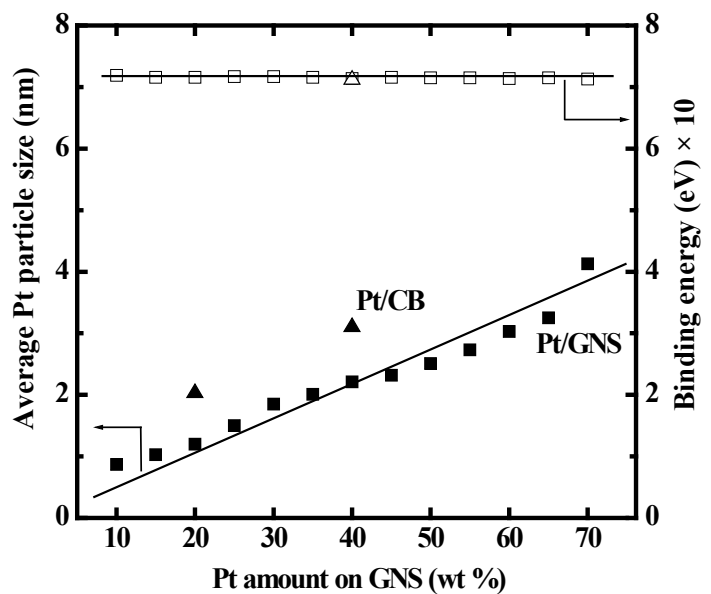

Fig. 4: Pt 4f binding energy (eV) (\% Pt/GNS, ${ }^{2} \%$ $\mathrm{Pt} / \mathrm{CB})$ versus onset potential $(\mathrm{V})$ versus $\mathrm{RHE}$
XPS

Figure 3, 3a and 4 show the relationship between Pt binding energies and particle size based on XPS measurement for 10-70 wt \% Pt/GNS and 20 and 40 wt \% Pt/CB commercial catalyst. It shows that the binding energies (BEs) decrease

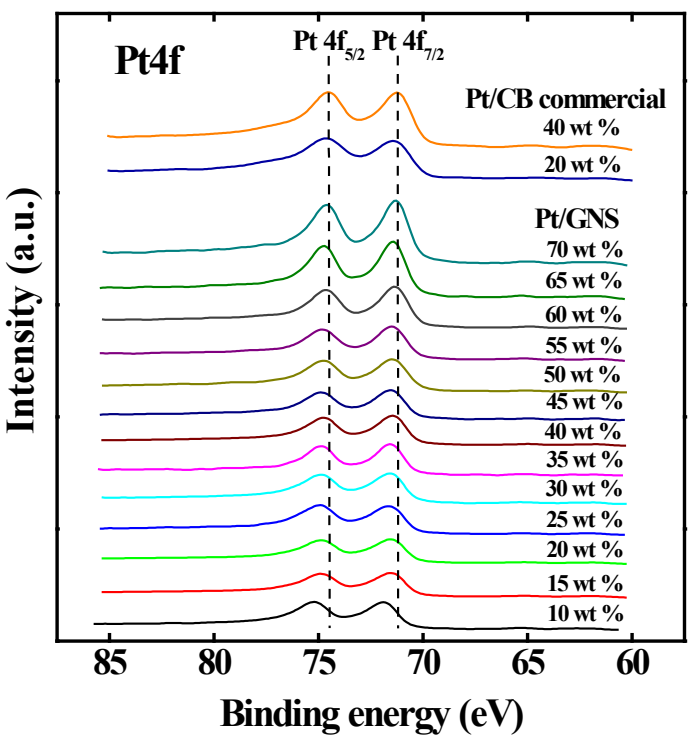

Fig. 3: XPS spectra of 10-70 wt \% Pt/GNS and 20 and 40 wt $\% \mathrm{Pt} / \mathrm{CB}$ commercial catalysts in the $\mathrm{Pt} 4 \mathrm{f}$ region. The results for the 20 and $40 \mathrm{wt} \% \mathrm{Pt} / \mathrm{CB}$ commercial catalysts are also shown

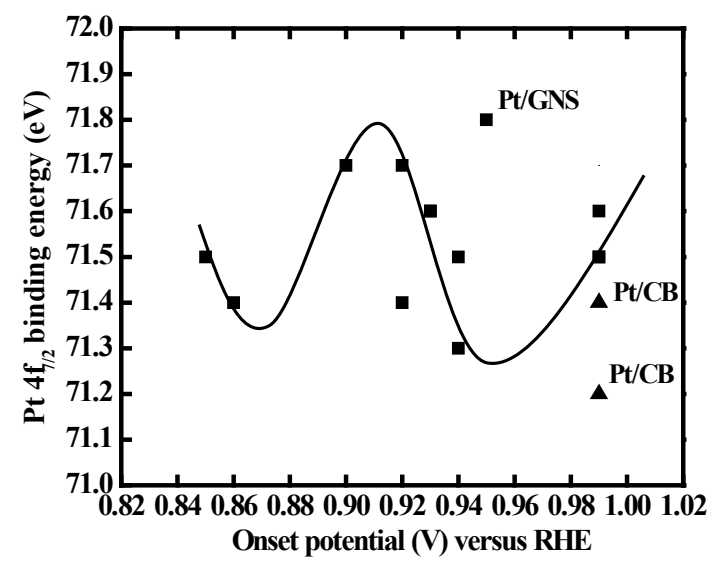

Fig. 5: Pt 4f binding energy (eV) ( \% Pt/GNS, $2 \%$ $\mathrm{Pt} / \mathrm{CB}$ ) versus current density at $0.9 \mathrm{~V}$ versus RHE (mA cm$\left.)^{-2}\right)$ 


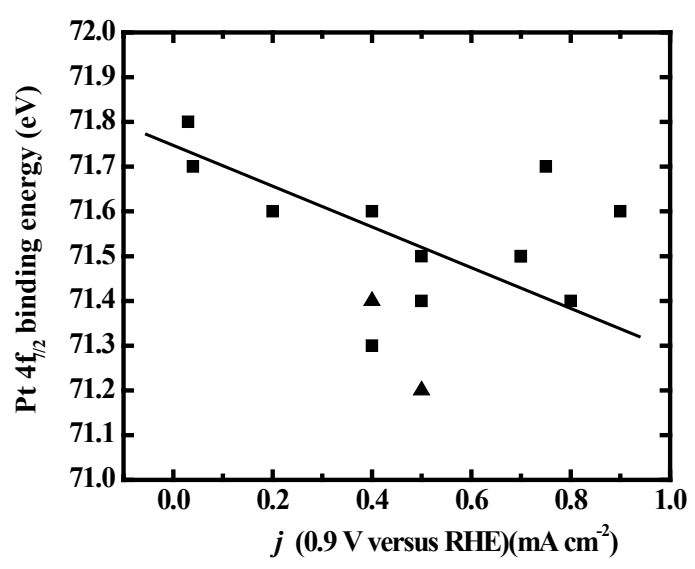

Fig. 6: Current density at $0.9 \mathrm{~V}$ versus RHE $\left(\mathrm{mA} \mathrm{cm}{ }^{-2}\right)$ ( \% Pt/GNS, $\left.2 \% \mathrm{Pt} / \mathrm{CB}\right)$ versus Pt $4 \mathrm{f}$ binding energy (eV)

with increasing Pt particle size. In addition, the $\mathrm{BE}$ of $\mathrm{Pt}$ on $\mathrm{Pt} / \mathrm{CB}$ is close to the bulk $\mathrm{Pt}(71.2 \mathrm{eV}){ }^{26}$ indicating the weak interaction between $\mathrm{Pt}$ and $\mathrm{CB}$. Interestingly, the BEs of Pt on Pt/GNS shifts to higher binding energy compare to $\mathrm{Pt} / \mathrm{CB}$. It indicates that the strong interaction between Pt and GNS. Therefore, the GNS can be expected to modify the $\mathrm{Pt}$ electronic structure. The relationship between $\mathrm{Pt}$ binding energy and ORR catalytic activity for 10-70 wt \% Pt/GNS and 20 and 40 wt \% Pt/CB commercial catalysts is shown in Figure 4. It clearly shows that the $\mathrm{Pt}$ binding energy is linearly related to onset potential. This data also consistent with Pt binding energy versus current density (Figure 5). These data indicate that the strong interaction between $\mathrm{Pt}$ and GNS, probably $\delta-d$ interaction may affect the

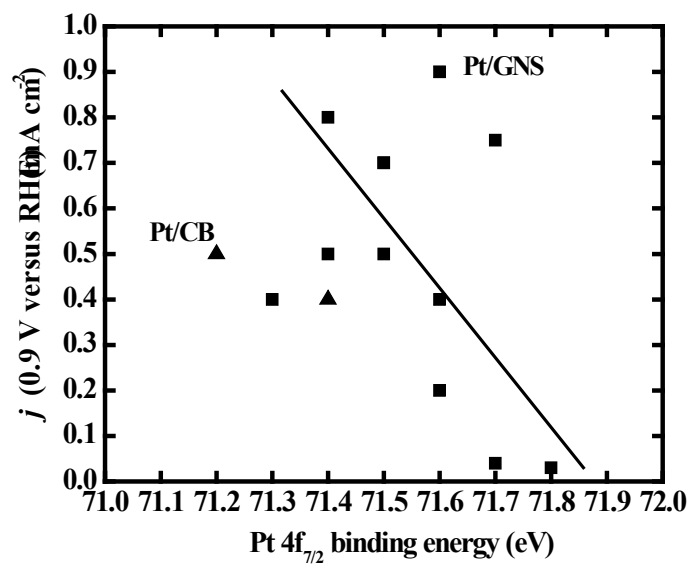

oxygen reduction catalytic activity. The 20 wt \% Pt/ GNS catalyst is very special because it has highest the ORR catalytic activity among the others. It is possible due to in this catalyst condition, the optimum condition for oxygen reduction can be obtained.

\section{CONCLUSIONS}

In this study, we used GNS as a support material to deposited $\mathrm{Pt}$ particles in order to investigate the support material effect for ORR activity. We found that the ORR activity of Pt/GNS is higher than $\mathrm{Pt} / \mathrm{CB}$ commercial catalyst. It indicates that the Pt electronic structure is modified by GNS. Therefore, the GNS as supporting material is better than CB for properties of Pt catalysts.

\section{REFERENCES}

1. Shao, Y.; Liu, J.; Wang, Y.; Lin, Y. Novel catalyst support materials for PEM fuel cells: current status and future prospects. J. Mat. Chem. 2009, 19, 46-59.

2. Gasteiger, H. A.; Markovic, N. M. Just a Dream - or Future Reality?. Science 2009, 324, 48-49.

3. Gasteiger, H. A.; Kocha, S. S.; Sompalli, B.; Wagner, Frederick T. Activity benchmarks amd requirements for $\mathrm{Pt}$, Pt-alloy, and non-Pt oxygen reduction catalysts for PEMFCs. Appl. Catal. B. Environ. 2005, 56, 9-35.
4. Peng, Z.; Yang, H. Designer platinum nanoparticles: Control of shape, composition in alloy, nanostructure and electrocatalytic property. Nano Today 2009, 4, 143-164.

5. Markovic, N. M.; Schmidt, T. J.; Stamenkovic, V.; Ross, P. N. Fuel Cells 2001, 1, 105-116.

6. Berger, D. J. Science 1999, 286, 49-50.

7. Kou, R.; Shao, Y.; Mei, D.; Nie, Z.; Wang, D.; Wang, C.; Viswanathan, V. V.; Park, S.; Aksay, I. A.; Lin, Y.;Wang, Y.; Liu, J. J. Am. Chem. Soc. 2011, 133, 2541-2547.

8. Shao, Y.; Yin, G.; Gao, Y. J. Power Sources 
2007, 171, 558-566.

9. Zhou, J. G.; Zhou, X. T.; Sun, X. H.; Li, R. Y.; Murphy, M.; Ding, Z. F.; Sun, X. L.; Sham, T. K. Chem. Phys. Lett., 2007, 437, 229-232.

10. Shao, Y.; Sui, J.; Yin, G.; Gao, Y. Appl. Catal., B 2008, 79, 89-99.

11. Yoshitake, T.; Shimakawa, Y.; Kuroshima, S.; Kimura, H.; Ichihashi, T.; Kubo, Y.; Kasuya, D.; Takahashi, K.; Kokai, F.; Yudasaka,M.; lijima. S. Physica B, 2002, 323, 124-126.

12. Park, K.W.; Sung, Y. E.; Han, S.; Yun, Y.; Hyeon, T. J. Phys. Chem. B, 2004, 108, 939-944.

13. Shao,Y.Y.; Yin, G. P.; Wang, J. J.; Gao, Y. Z.; Shi, P. F. J. Power Sources, 2006, 161, 47-53.

14. Bessel, C. A.; Laubernds, K.; Rodriguez, N. M.; Baker R. T. K. J. Phys. Chem. B, 2001, 105, 1115-1118.

15. Wang, J.; Yin, G.; Shao, Y.; Zhang, S.; Wang, Z.; Gao, Y. J. Power Sources 2007, 171 331-339.

16. Sun, C. L.; Chen, L. C.; Su, M. C.; Hong, L. S.; Chyan, O.; Hsu, C.Y.; Chen, K. H.; Chang, T. F.; Chang, L. Chem. Mater., 2005, 17, 3749-3753.

17. Shao, Y.Y.; Yin, G. P.; Wang, Z. B.; Gao,Y.Z. J. Power Sources, 2007, 167, 235-242.

18. Stoller, M. D.; Park, S.; Zhu, Y.; An, J.; Ruoff, R. S. Nano Lett. 2008, 8, 3498-3502.

19. Novoselov, K. S.; Geim, A.; Morozov, S. V.; Jiang, D.; Zhang, Y.; Dubonos, S. V.; Grigorieva, I. V.; Firsov, A. A. Science 2004, 306, 666-669.

20. Antolini, E. Applied Catalysis B: Environmental 2012, 123-124, 52-68.
21. Cherstiouk, O. V.; Simonov, P. A.; Savinova, E. R. Electrochim. Acta 2003, 48, 3851-3860.

22. Hummers, W. S.; Offeman, R. E. J. Am. Chem. Soc., 1958, 80, 1339.

23. Stankovich, S.; Dikin, D. A.; Dommett, G. H. B.; Kohlhaas, K. M.; Zimney, E. J.; Stach, E. A.; Piner, R. D.; Nguyen, S. T. ; Ruoff, R. S. Nature 2006, 442, 282-286.

24. Siburian, R.; Nakamura, J. J. Phys. Chem. C 2012, 116, 22947-22953.

25. Joo, J. B.; Kim, P.; Kim, W.; Kim, Y.; Yi, J. J Appl. Electrochem. 2009, 39, 135-140.

26. Vidakovic, T.; Christov, M.; Sundmacher, K. Electrochim. Acta 2007, 52, 5606-5613.

27. Cherstiouk, O. V.; Simonov, P. A.; Savinova, E. R. Electrochim. Acta 2003, 48, 3851-3860.

28. Moulder, J.; Stickle, W. F.; Sobol, P.E.; Bomben, K. D. Handbook of X-ray Photoelectron Spectroscopy; Perkin Elmer Corporation: Minnesota, USA, 1992; pp. 6, 8, 40-43, 78.

29. Qu, L.; Liu, Y.; Baek, J. B.; Dai, L. ACS Nano 2010, 4, 1321-1326.

30. Imamura, G.; Saiki, K. J. Phys. Chem. C. 2011, 115, 10000-10005.

31. Gong, K.; Du, F.; Xia, Z.; Durstock, M.; Dai, L. Science 2009, 323,760-764.

32. He, D.; Cheng, K.; Li, H.; Peng, T.; Xu, F.; Mu, S.; Pan, M. Langmuir 2012, 28, 3979-3986.

33. Shao, M.; Peles, A.; Shoemaker, K. Nano Lett. 2011, 11, 3714-3719.

34. Pozio, A.; De Francesco, M.; Cemmi, A.; Cardellini, F.; Giorgi, L. J. Power Sources 2002, 105, 13-19. 